\title{
Academic Status for University Librarians-A New Approach
}

A CADEMIC or faculty status for college and university librarians is one of those issues which persists in reappearing at frequent intervals. The wide diversity of policies now in effect is evidence of the fact that no uniform or standard practice has been evolved, and perhaps the lack of agreement indicates that no ideal solution applicable to all types of educational institutions can be found.

McMillen, ${ }^{2}$ Maloy, $^{2}$ and Estes ${ }^{3}$ have noted some of the varied plans adopted by colleges and universities in the United States. Only the chief librarian is given academic rank in certain institutions; in others, the assistant or associate librarian and, occasionally, department heads are included. Subordinate members of the staff, at least in the universities, are ordinarily not accorded faculty standing.

Substitute arrangements are relatively common. For example, librarians may be classified as administrative employees or they may be assigned ranks "equivalent to," but not actually identical with, those of faculty members-a scheme likely to give the librarians involved a very hazy status indeed. A few universities attempt to meet the problem by setting up the library staff in a separate professional category, on the theory, apparently, that librarians are so unlike any other group in the institution

1 McMillen, James A. "Academic Status of Library Staff Members of Large Universities." College and Research Libraries I:138.40, March 1940.

2 Maloy, Miriam C. "Faculty Status of College Librarians."' A.L.A. Bulletin 33:232-33, 302, April I 939.

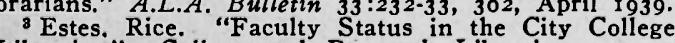
Libraries." College and Research Libraries 3:43-45, December I94I. they do not fit any established classification. Almost any definite plan is preferable to the confused situation prevailing in too many colleges and universities which fail to define suitably the place of librarians in their organizations, letting them fall, usually, in the nebulous region between clerical and teaching staffs.

Each of the types of library staff classifications referred to above, it should be noted, represents a compromise. But, why not go all the way? Are not librarians so completely identified with the college or university's primary program (assuming their jobs are being properly done) that they are entitled to full recognition as an integral part of the academic group? Certainly they are performing functions similar in kind to those carried on by the teaching staff. That point of view has been eloquently presented and defended by Wriston, ${ }^{4}$ Bishop, ${ }^{5}$ and others. It was on this assumption that a general reorganization of the University of Illinois Library staff recently took place.

A brief historical review is needed for discussion of the events at Illinois, with which the present article is mainly concerned. In I9I I the university library staff was placed under state civil service and, except for a few department heads, remained there for some thirty years. Later, the university was permitted by special

\footnotetext{
1Wriston, Henry M. "The College Librarian and the Teaching Staff." A.L.A. Bulletin 29:177-82, April 1935 .

"Bishop, William Warner. "The College Library and College Teaching." Bulletin of the Association of American Colleges 23:190-200, May 1937.
} 
legislation to set up its own civil service system, and librarians were transferred to the new organization. From the point of view of the library staff, numerous disadvantages were encountered in connection with civil service, both state and university. Among major weaknesses of the systemfaults inherent to some extent perhaps in all civil service organizations-were the following:

I. The tendency of civil service to restrict recruiting and selection of candidates for library positions, because residence requirements and the method of announcing examinations limit the eligibility of desirable candidates from other states and fail to inform them when examinations are to be given

2. The difficulty in preparing suitable examinations and requiring appointees or prospective appointees to submit to such examinations

3. Failure of civil service to promote effcient service, while reducing initiative and ambition

4. Transfer of many vital aspects of control of the library staff from the library administration to civil service officers

5. Lack of success of civil service procedure in obtaining qualified library staff members, with no assurance that persons standing high on eligibility lists would be prepared to fill specialized positions

6. Failure of established civil service regulations to meet standards for vacations and sick leaves widely accepted in the library profession.

Less tangible than the above factors, but nevertheless a fundamental consideration, was a certain stigma felt by the library staff in being classified as civil service workers, for they alone among all university employees primarily engaged in academic activities were singled out for such designation. Research workers, extension workers, high school visitors, student counselors, experiment station workers, and the health service, for example, were grouped with the academic, rather than the nonacademic, staff of the university.
Among relatively minor objections to the system was civil service terminology. Such terms as principal library assistant, senior library assistant, library assistant, and junior library assistant, used to cover a majority of the staff, were virtually meaningless in describing a position or in giving any definite idea of an individual's functions.

To alleviate some of the most unsatisfactory aspects of civil service, a proposal was made to create a professional library group within the framework of the civil service organization. Such a plan would, of course, have given recognition to special training and duties but would have met none of the principal objections to including librarians under civil services rules and regulations.

When this impasse was reached, a recommendation was submitted to the president and trustees of the university asking that librarians be included in the academic staff, thereby automatically removing them from the classified university civil service. After careful study of all interests affected, the request was approved in June 1944. In order to make the change, certain revisions were required in the university statutes, including a redefinition of academic staff. The new definition reads as follows:

The academic staff which conducts the educational program shall consist of the teaching staff, the research staff, the extension staff, deans, directors of educational departments, high school visitors, librarians, and such other members of the staff as are designated by the president.

It should be pointed out that the change of status for librarians applied to the professional staff only. Clerical members, whose functions are similar to those of other office workers at the University of Illinois, were not affected and continue to be governed by civil service procedures. 


\section{Campaign for Change}

In coming to the decision to place librarians in an academic category, the university administration was undoubtedly influenced by a long educational campaign. A detailed job analysis was drawn up for every position on the library staff, with a full statement of qualifications and duties. It was found that about twenty librarians had regular teaching responsibilities, including library school lectures, courses in the use of the library, instructional tours of the library, and participation in courses offered by other departments. A considerably larger number, perhaps fifty, were actively engaged in research or directly assisting faculty and graduate research programs. In this group were reference librarians, departmental librarians, bibliographers, and catalogers. Less directly, but just as concretely, a sound case could be made out for the aid given teaching and research by other members of the library staff.

\section{Educational Preparation}

Also an influential factor in bringing about reclassification of the librarians was their educational preparation. After all, arguments for academic status have a weak foundation unless librarians can bring to their jobs preparation and training similar or equivalent to that possessed by the teaching faculty. An investigation of the Illinois library staff lent support to the plea for academic recognition. Analysis showed fifty librarians with master's or doctor's degrees in library or special subject fields. Forty-three staff members had one year of professional training beyond college graduation, and most of these assistants were working toward master's degrees. In short, over 50 per cent of the staff had from two to four years of professional training, comparing favorably in this respect to the instructional group. Frequently, especially in the case of departmental and divisional librarians, combination training was required, including not only a library school degree but knowledge of such fields as chemistry, biological sciences, law, agriculture, engineering, education, art, medicine, modern and classical languages, history, social sciences, and journalism.

\section{Questions of Policy}

Having achieved long-sought-for academic standing, numerous questions of policy for the library staff remained to be settled. First was the matter of titles. Some difference of opinion existed on this point, but it was finally agreed that academic terminology fits librarians only in part, even though everyone recognized that they are classified logically with the academic group. Accordingly, academic titles, e.g., "instructor," "assistant professor," "associate professor," etc., were assigned only to those having actual teaching responsibilities, a total of twenty individuals. There was left the problem of determining where the remainder of the staff belonged in the academic scheme, for in working out salary scales, making promotions, and in deciding questions of academic privileges, it was advantageous to have all librarians grouped by academic ranks. Provision was therefore made to give rank, but not titles, to approximately ninety staff members. These ranks are shown in contracts, directories, catalogs, and any other sources in which the librarians' names may be listed, thus clearly defining their status.

In addition, having dropped the ambiguous civil service classifications and terminology, all staff members were assigned professional titles descriptive of their positions and grouped in four categories. Following is an outline of the revised classification, showing both academic and library titles: 


\section{GROUP I}

Library Assistants with the Rank of Assistant (Includes full-time and part-time assistants in all departments of the library.)

Typical positions:

Acquisition Assistant

Exchange Assistant

Periodical Assistant

Binding Assistant

Catalog Assistant

Circulation Assistant

Reference Assistant

Law Library Assistant

\section{GROUP II}

Librarians with the Rank of Instructor (title when teaching)

(Includes assistant heads of medium-size departments, heads of departmental divisions, revisers, catalogers, bibliographers, specialists in subject and library science fields, librarians in charge of some college and departmental libraries, and assistant reference librarians.)

Typical positions:

Bibliographer

Gift and Exchange Librarian

Exchange Reviser

Assistant Binding Librarian

Catalog Reviser and Serial Reviser

Assistant Circulation Librarian

Catalogers and Serial Catalogers

Extension Loans Librarian

Reserved Book Room Librarian

Freshman Reading Room Librarian

Book Stacks Librarian

Newspaper Librarian

Assistant Reference Librarian

Some college and departmental librarians

Browsing Room Librarian

Library Administrative Assistant

\section{GROUP III}

Librarians with the Rank of Assistant Professor (title when teaching)

(Includes heads of departments, librarians of large departmental libraries, assistant heads of large departments, senior specialists in bibliography, cataloging, reference, administration, and subject fields.)

Typical positions:

Circulation Librarian

Reference Librarians

Bibliographic Consultant
Assistant Catalog Librarian

Assistant Acquisitions Librarian

Associate Reference Librarian

Natural History Librarian

Agricultural Librarian

Engineering Librarian

Architectural and Fine Arts Librarian

Medical Librarian

Law Librarian

\section{GROUP IV}

Librarians with the Rank and Title of Associate Professor

(Includes assistant university librarians for acquisition, cataloging, public service, personnel.)

For each of the four groups there was drawn up a detailed analysis defining the duties performed, experience needed, and educational and personal qualifications required. These comprehensive descriptions supplement the job analyses prepared for each established position on the staff. In order to lend flexibility to the system, it was provided that stated qualifications may be relaxed to make possible the employment of librarians with specialized training who lack some of the formal requirements.

Along with disposition of these matters, it was undertaken to clarify university policy on salary scales, tenure, promotions and demotions, vacations and holidays, disability and sabbatical leaves, hours of work, and retirement benefits. As finally approved, for these several purposes, the librarians were grouped in some instances with the teaching faculty and in others with administrative officers. For tenure rules, disability leaves, sabbatical leaves, and retirement benefits, librarians receive identical treatment with the teaching staff. Salary scales also correspond to those of similar ranks in the instructional group, with some recognition of the fact that, in the case of persons on the teaching staff, service is required only during the two semesters of the regular academic year, beginning in Sep(Continued on page 26) 
it through their local libraries.

When the enemy was approaching Moscow, the library's staff, helped by the citizens of Moscow, took all possible steps to preserve the collections. By then the most precious editions already had been transported to the interior of the country. A good part of the books, however, remained in the capital. During the enemy's raids, library workers took up posts on the roof and attics of the library to extinguish incendiaries dropped by Nazi bombers. Recently thirty-eight members of the library's staff were awarded the For Defence of
Moscow medal for their gallant services in those perilous days.

Today the Soviet people are happy in the knowledge that their great efforts and sacrifices were not in vain. The personnel of the Library of Historical Research, along with the libraries all over the Soviet Union, derive inspiration from the fact that their labor is highly valued by the government both in war and peace. Additional. proof of this is the considerable rise in salaries recently granted to all library workers, despite the great demands made by the war on the country's budget.

\section{Academic Status for University Librarians}

\section{(Continued from page 9)}

tember and ending in June, while librarians are on twelve-month appointments. For hours of work, vacations, and holidays, librarians are grouped with general administrative officers. This means a work week of thirty-nine hours, an annual vacation of one month, and all holidays observed by the university. Incidentally, analogous provisions govern the university's nonteaching research staff in various departments.

\section{Summary}

In summary, it is the conclusion of those who have given long study to library staff problems at the University of Illinois, first, that professional librarians, by the nature of their functions, definitely belong in the instructional and research group; second, by comparative standards of education and preparation, they qualify for inclusion with the teaching staff; and, third, there are numerous tangible and intangible advantages for librarians in holding an academic classification. With reference to the last point, the factor of staff morale is of primary significance. One can expect the best results from any organization only if its place is clearly understood and appreciated. The improved status of librarians at Illinois is certain to play a major part, as time goes on, in the development of a library staff with a high sense of professional pride and responsibility, conscious of the importance of its work, and receiving proper compensation and recognition for its contribution to the institution. 